\title{
US genome head faces charges of conflict
}

\section{Watson expected to leave this summer - Feud with Healy, Bourke led to showdown}

\section{Washington}

NoBEL Laureate James Watson, the director of the US National Institutes of Health (NIH) genome project, is under investigation for alleged conflict of interest and is expected to resign his position rather than fight what his associates say is a concerted campaign to unseat him.

NIH officials say that Bernadine Healy, the NIH director, has raised concerns about stock that Watson owns in biotechnology and gene sequencing companies that she feels represents a possible conflict of interest. Healy reviewed Watson's files and told the agency's ethics officer, Jack Kress, about a number of such holdings. Kress, who met with Watson on 24 March, believes that Healy could resolve the conflicts by simply signing a waiver to allow Watson to keep the stocks. But Healy "has concerns about signing a waiver" and is reluctant to make such an exemption given the volatile nature of the issue, according to her spokeswoman, Joanna Schneider.

Although Watson could sell the stock in question and resolve the issue, he has told associates that he instead will resign, perhaps as early as 1 August. Contacted at home early this week, Watson said he had been forbidden to talk about the situation and would not comment further.

Watson's associates are concerned that the alleged conflict of interest is merely a smokescreen. They believe that lastmonth's showdown marks the latest turn in a running feud between Watson and Healy that has been fanned by Watson's vocal opposition to Healy's decision to file a patent for cDNA sequences last summer (Nature 353, 485 ; 1991) and his attempts to derail a gene sequencing company proposed by Frederick Bourke, a wealthy entrepreneur (Nature 355, 483; 1992).

Known for his outspoken and often acerbic leadership of the US genome project, Watson's three-year tenure at NIH has been controversial from the start. But in opposing Bourke, who is friendly with several prominent politicians in Washington, including Senate Majority leader George Mitchell, Watson appears to have made one enemy too many.

Bourke has been trying to sign up two prominent gene sequencing researchers - Robert Waterston of the Washington University in St. Louis and John Sulston of the UK Medical Research Council (MRC) Laboratory of Molecular Genetics at Cambridge - as the core of his new company. Watson feared that such a move might halt one of the most productive collaborations in the genome project and has tried hard to block it.

For example, in February Watson met with MRC officials in Britain to urge them to give Sulston more money to keep him in place. MRC apparently agreed. Sulston has not joined Bourke's company (which is not yet incorporated or named) and the

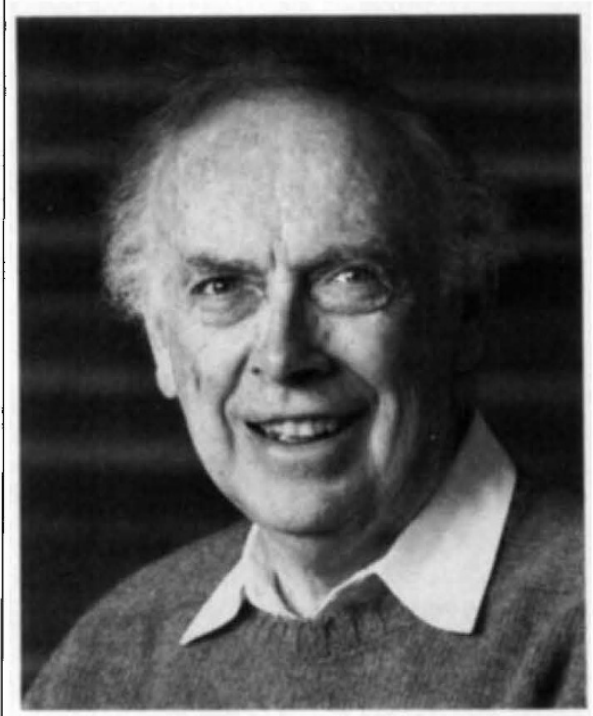

Watson may resign over charges.

MRC is planning to increase Sulston's funding significantly, although it has not released any details.

While in Britain, Watson also met with officials at Glaxo, the British pharmaceutical company. Accounts of the meeting differ, but Bourke, in a letter last month to Healy and White House officials, alleged that Watson encouraged Glaxo to start its own gene sequencing company centred around Sulston. Such a step would have pre-empted Bourke's plans. In his letter, the details of which have been confirmed by several sources, Bourke also alleged that Watson owns some Glaxo stock and stands to profit should the new venture become a success.

Late last month, after receiving the Bourke letter, Healy passed the allegations on to Kress. "She has a concern about the appearance of, and actual, conflict of interest" in the charges, says NIH's Schneider. "The public deserves to know that there is no conflict of interest - that's Dr. Healy's responsibility."

But Kress disagrees, and says that he found "no substance" to Bourke's charges. The allegations "gave me pause", he says, "but after talking it over with Dr. Watson, I was satisfied that there was no conflict."

Because Watson continues to serves as director of the Cold Spring Harbor Laboratory, which receives $\mathrm{NIH}$ funding, he has already removed himself from the NIH grants process. Although Kress dismissed the allegations contained in the Bourke letter, he determined that some of Watson's other stock holdings might pose a conflict because of the impact of Watson's decisions on the entire biotechnology industry. He says he intended to recommend a waiver after a second meeting with Watson this week, despite Healy's resistance to such a resolution.

Kress confirmed that Watson told him he was planning to resign over the issue. But he emphasized that "there is no ethical reason for him to leave. I am in no way, shape or form recommending that he step down based on anything we discussed."

Watson is said to be treating Healy's ultimatum as a virtual sacking. Schneider says Watson has not been fired. "It's not as sinister as it seems," she says, "but there were some concerns expressed that need to be looked into. Some very difficult decisions are going to have to be made."

Although his associates say that Watson periodically has threatened to resign as a negotiating tactic, they say that this time is different. Norton Zinder, a Rockefeller University geneticist and former chairman of Watson's genome advisory panel, describes the clash as "a political in-fight that has unfortunately reached an impasse."

Earlier this year, NIH officials reviewed Watson's files and found that conflict-ofinterest concerns had been raised several times over the past few years. But there is no record in the files of any waiver or other resolution of the issue, according to one official. Bourke's letter appears to have reinforced Healy's resolve to confront Watson on the issue. Watson's "relations with Healy have never been good," says Rich Roberts, Watson's deputy at Cold Spring Harbor, "but the letter from Bourke may have been the last straw."

Researchers are concerned that their feud may damage NIH and the genome project. Coming only days after congressional hearings on the agency's budget, and during a year in which funding is already squeezed by economic concerns, a battle between Watson and Healy could mean a leadership vacuum that costs both the agency and the genome project millions of dollars. Both Zinder and Robert Cook-Deegan, an analyst at the Institute of Medicine and a confidant of Watson, say they have urged Watson to remain on the job until the agency's funding is set, probably sometime in early autumn. But Kress says that Watson "is feeling the crush" and will probably resign sooner than he had planned.

Christopher Anderson 